\title{
Fertility Decrease and Son Preference Among the Educated Middle-Class in Kathmandu
}

\author{
Bishnu Prasad Dahal \\ Correspondence: Department of Anthropology, Patan Multiple Campus, Patan Dhoka, Tribhuvan University, \\ Kathmandu, Nepal
}

Received: February 14, 2021 Accepted: March 15, 2021 Online Published: March 31, 2021

doi:10.5539/res.v13n2p1

URL: https://doi.org/10.5539/res.v13n2p1

\begin{abstract}
The aim of this research article is to explore the persistence of single child especially the son preference in a Hindu dominated patrilineal, patrilocal society found in Kathmandu is facing the midst of fertility decline. Using semi-structured interview schedule with the help of observation and ethnographic field work mostly in middle class families of Kathmandu, I have tried to analyze the role of socio-cultural factors in selecting the number of baby conceiving and give birth, gender of child etc. regarding reproductive health and concern were questioned to married women and which remained intact. Fertility decrease or increase is not due to the only the demographic factors, it is due to the multiple factors; social factors, cultural, ecological, economic, religious and psychological, political etc. that's why, due to various reasons fertility is decreasing day by day in one hand and in other hand son preference is increasing day by day. People usually working couple do not want more than single child and they want to give birth a single son. It impacts on population composition, sex ration, increase abortion, familial quarrel etc. Son preference is because of multiple reasons; economic, religious, cultural, social, political familial, lineage system, customs, norms values, attitudes etc.
\end{abstract}

Keywords: fertility decrease, son preference, sex selection, religion, society, ecology, economy, socialization, sociobiology, psychology, political, lineage

\section{Introduction}

Fertility decrease is associated with multiple factors. Though it is a demographic phenomenon but associated with many others factors like economy, social composition, ecology etc. Among demographic factors; fertility is directly related with the age at a marriage, mortality and migration. Here in this research paper I would like to find out the interrelationship between fertility decrease associated with child birth number especially son in Hindu society in Kathmandu valley.

The country has their own trend to develop the human resources in their own demand and society has developed their norms and values regarding sex ratio or gender ratio inside the country to maintain the equilibrium among and between them so as to maintain the harmony, solidarity and integration in the respective society in one hand and in other hand there are so many social context and social stigma to practice the discrimination and disparity among and between the genders in terms of sex or gender identity. So, sex selection has been perceived as one of the important stigma for the preference of son in orthodox society of Hindu like Kathmandu. It is found that the son preference is highly practiced in mostly patriarchal society where son born as a elite class perceptually. Not only in the society like patriarchal society and orthodox Hindu society, son preference has got high value in all over the world and it is a global phenomenon that the sex-selective abortion do not control to prevent sex selection globally and it never work to control the phenomenon of son preference. Among various methods there are effective medical methods to find out the sex of baby before born and it helps to find out the sex of a fetus before birth. Despite these other methods are also important but they are quite difficult to practice such as sperm sorting and pre implantation genetic diagnostics in all society where the developments of such facilities are less (Barot, 2012). Pre birth sex or gender identification or selection is a global problem which is growing day by day and there should be broad international consensus that may check up or control the sex selection during pre birth by implementing the gender equality or gender equity in society.

It is found that the state legislatures of the most of the countries have adopted various specific abortion policies and abortion restrictions that target specifically for women of pregnancy conditions by restricting abortion on the basis of prebirth gender identification and sex selection including genetic anomaly. In recent years, the rights of women in their own body, abolishment of gender based discriminations and inequalities related laws including abortion laws have introduced federal legislation that would prohibit abortion based on the sex of the fetus in general conditions, but in case of specific conditions law provided the rights of abortion. Similarly, some countries have adopted laws regarding the sexual rights 
and duties that require patients receiving a diagnosis of a fetal sex, health conditions, growth and genetic condition be given information for the health and medical reason, but in case of the identification of sex of fetus for the give birth of son is should be strictly prohibited. In such conditions, abortion is prohibited by the laws and the provision of pre-birth identification of fetus and fetal genetic anomaly restrict women's ability to make decisions that are best for their health themselves and their families socially.

Several countries have approved laws that prescribe abortion in cases of fetal genetic anomaly, gang rape, raped by own blood kin's including in circumstances where the fetus cannot survive outside the womb. The identification of the sex of fetus is strictly prohibited by the laws, except in the case of the sensitive medical conditions or disability, comprehensive pregnancy options, and resources for the child and family.

However, there are various methods and services are available in the sector of the sexual or reproductive health especially for women to prevent unwanted pregnancy, forced raped, etc. but in case of family reproductive health which mainly focus the identification of pre- birth of sex of fetus and if parents do not want to give birth the baby in general condition of the baby, then abortion opponents have used these bills to preventing patients from receiving information about abortion as an option to consider in response to a diagnosis (Barot, 2012).

A strong gender preference among parents particularly a single child they rigorously search that is mostly a "son". The selection of gender in pre-birth or son preference is somehow related to a particular socio-cultural stigma and discriminatory gender roles in a society which stem from economic, social, cultural, religious, and psychological contexts (Gupta et. al 2003).

In particular in society or in orthodox society like Hindu society, where rigid patriarchy acts as the socio-cultural value system and patrilineal and patrilocal kinship systems regulate inheritance property rights for son only, male usually gets higher wage than female, transfer of parential inherient property only through the son, allocation of productive assets (such as land) and old age support and where a strict labor division exists, sons are preferred than daughters (Gupta et. al 2003).

Globally, due to the development of various medical, health facilities and services, preventive methods about the reproductive health are getting priority than curative. Although, female feticide is illegal under the prevailing existing law of Nepal (Puri et.al, 2007), it is accepted legally, with some conditions like gang raped, forced raped and raped by own kin's by "The Right to Safe Motherhood and Reproductive Health Act 2018". With the development of various well facilities, services on modern reproductive health technologies, infanticide has been replaced by feticide all over the world. In Nepal, it is found that female infanticide was common for getting dowry (gifts from parents and relatives, neighbors etc..) bringing by bride from her natal home as gift was still practiced in one hand and in another hand male gets high wage than female in similar work mostly in the agriculture (Miller, 1997). That's why, it is assumed that without son the subsistence agriculture is mostly impossible to sustain and continued inherently in Hindu orthodox societies and the patriarchy functions to build the perceptions and value system for all members of the family, society and culture they have practiced. The gender based discriminations, inequalities, disparities in the societies are basically analyzed by the study of the sex or gender ratio, child mortality rate, fertility rate based on gender, rate migration based on gender and for other gender-related differences (e.g., accidental deaths are more common among boys than among girls) (Unnithan-Kumar, 2010).

Nepal is a diversified country in terms of caste, class, religions, ecology, and structure of society and features of culture. It is found that though country is diverge in many aspects, it is a common garden of all peoples- haves or haves not economically, in terms of educations, languages and cultures and their living styles and standards are mismatched. The geography of the country can be divided into three ecological regions: the terai (plains area), the hills and the mountains. Life of one region is quite different than other regions with wide disparities in the living standard and access to the opportunities and physical facilities. On the basis of population, the composition of nation's population in diverse and mostly heterogeneous in nature in terms of caste, class, religion, language, ecology etc. based distributions.

Now, the population of Nepal is about 27 million with a growth rate of 1.4 percent (CBS, 2011). It is noted that there are 103 listed diverse ethnic/caste groups, each with its own distinct languages and culture in the 2001 Population census. Nepal is primarily a Hindu dominated country with more than 81 percent of its population are Hindus. The recent Demographic and Health Survey of Nepal (2011) found that the total fertility rate is 2.6 per woman, reduced from 4.1 in 2001 (DHS, 2011).

Majority of the population lives in village, rural and remote areas, where physical facilities and infrastructures with basic services are very poor. In studying the issue of fertility decline in case of Nepal, it is noted that the increasing facilities of reproductive health like; increasing facilities of reproductive health, and improving the family planning programs are not only the reason that helps to decrease the fertility. Despite these, increase of age at a marriage, decrease of mortality rate especially child mortality, life expectancy, change in over all reproductive behavior including migration of male etc are 
now growing new trends in population dynamics.

The abortion law was legalized in Nepal in 2002, strictly prohibits sex determination and sex selective abortion. A woman can legally obtain an abortion up to 12 weeks' gestation, up to 18 weeks in case of rape or incest, and at anytime during pregnancy if she feels her life is at risk or the fetus has congenital anomalies. However, after the legislation of abortion, concern has been raised about sex selective abortion in Nepal (CREHPA/UNFPA, 2007a). Not in only reproductive health, in other sectors, Nepal has made progress in reducing gender-based discrimination and empowering women and they have significantly better access to education, economy, politics, profession, participation and decision making too. Through the legal reforms women are strengthening their access, opportunities and strengthened in order to ensure gender equality and gender based empowerment. In addition to the legalization of abortion, the Domestic Violence and Punishment Act were passed in May 2009 in Nepal.

In Hindu orthodox society, patriarchy, the Hindu ideology, beliefs, norms, attitudes and values have helped to enforce the various forms of discrimination, disparities, inequalities and injustice based on gender. Despite several socio-cultural and legal reforms, various types of gender discriminations, inequalities and gender based violence are still persistent mostly in rural and even in urban Nepal which is resulted by the socio-cultural context of the society (Dahal, 2020b). The cause and effect of gender discrimination on children is basically analyzed by the study of the broader soci-cultural spectrum of the particular society and culture especially with the study of sex-specific child mortality rate and higher mortality rate of girls than that of boys indicates that the discriminatory caring system, beliefs and values of children especially based on the gender and mainly girls children were got less priority than boys. In South Asian region, overall childhood mortality continues to decline, the relative plight of girls has worsened (Agnihotri,1995).

Son preference in Hindu society promotes more extreme forms of socio-cultural discrimination, cultural values, norms, and attitudes including feticide or infanticide of females (Karki, 1992). As a son is very highly prioritized, valued and daughter is treated as supportive role for sons continue the family name, continue their lineage, transfer of parental properties inherently in lineage system, can perform funeral rituals are and expected to provide support in old age. This patrilineal social structure discourages women from practicing contraception until they have a son (Karki, 1992). If the women conceive the first child a son then she will never thought to conceive another child whether it is son or daughter. Ultimately it promotes the contraceptive use and fertility levels decreases, but also on the progress of fertility decline.

The relationships between fertility and the economy especially in case of rural Nepal - agriculture and remittances and urban is trading and job holding for subsistence were studied. It was found that fertility and economy; property (landholding), occupations, income are related through the holds that owned economic resources and economic opportunity, economic resources and opportunities holds that cultivated landholding (children can assist in tilling the land) in case of agriculture and in case of trading family assisted (the business to generate the economy) and fertility are complements since. Remittances are purported to affect fertility through increasing son preference. This is because remittances provide security and sons send remittances. This implies that the people of rural Nepal value children for the economic benefits while in urban it is generated through the trading and holding jobs in professional fields, they can bring. The economic value of sons vastly outweighs that of daughters and the findings of this research indicate that increasing remittances and high levels of functionally landless, property less, occupation less i.e. economy less households mean that son preference is unlikely to disappear soon.

In another hand, the economic theories of fertility transition have been neglected and are important for our understanding of fertility determinants - they are therefore extremely relevant for demographers, anthropologist and social scientists because without population especially fertility others factors are less important. In case of Nepal, it was also found that the quality of urban fertility is ignored by researcher and rural fertility is focused. Now the socio-economic factors of society and cultures are undergoing change and the contribution of urban fertility is also increasing in economy and it relates to economic variables in a substantively different way to urban fertility.

\subsection{Focus of the Research}

This research is framed as focusing on the searching the answers of these questions as; socio- cultural factors are the major determining factor for the single child especially son that found in the study of middle class families among Hindus of Kathmandu valley. What are the responsible factors for the fertility decline in Kathmandu?

The overall objectives of the paper are to study the dimensions, nature and determinants of Nepalese people's attitudes, social practices and cultural patterns towards single child and son preference and gender-based violence. The general objectives of the article are:

This research is conducted to identify the current behaviors of men and attitudes on a wide range of issues as they relate to gender equality. Another objective of the study is to examine the knowledge and attitudes of men and women toward single child especially son preference and fertility decrease. It is essential to explore responsible and determining factors 
that can be attributed to attitudes and behaviors of men and women related to gender-based violence especially for son preference, while studying the interrelationship between fertility decrease and son preference in Hindu orthodox society.

The specific objectives of this paper is to identify the interrelationship between the single child conceiving attitude, son preferences and fertility decline in middle class family in Kathmandu. It is examined that; Why has fertility in educated people of middle class family in Kathmandu recently found declining? Why they have the small family size, single child, attitudes of son performance? Is it because of the lack of economic resources or lack of time to grow the child? What will happen in coming future if the situation is continued? This paper describes the overall scenario of fertility decline, small size of family, single child, son preference etc in a wider perspective.

\section{Theoretical Review}

Usually, fertility decrease and son preferences are quite different issues but here I am using these concepts as co-related and reciprocal with one another.

\subsection{Theories about Fertility Decreases}

Son preference in Hindu society of Kathmandu is visualized through the various theoretical perspectives. For this the environmental assessment and economic realities should be understood for the application of appropriate theories for the selection of gender and number of child they want to conceive. In case of working husband and wife it is very difficult to rare and cares more than a single child and that child should be the son. There is presumption about financial constraints and professional career that most of the couples cannot afford, cannot manage time and cannot maintain the health and mentality for another child. There is denial about the possibility of postnatal depression that makes some women anxious about giving birth for a second time. It is assumed the advantages of son preferences mostly single include undivided inherent parental property and full attention and investment of parents for single son, responsibility of the parents limited and concentrated to looking only one child, and less economic stress and strain. Now a day, in Kathmandu it is very hard to find out the joint family and it is increasing competitive environment without support from the joint family and extended families and most of the couples find it hard to accommodate the needs of even a single child, especially when both the partners are working. In such situations, parents might find it easier to groom a single child.

Sexual selection refers to the differential ability of individuals with different phenotypes to compete successfully for mates. Sexual selection increases the chances of an individual's reproductive success and mate selection is generally guided by fitted genes in terms of physically, mentally, socio-culturally advances and smarts for individual's reproductive success. Sex selection in favor of boys is a symptom of pervasive social, cultural, political and economic injustices against women, and a manifest violation of women's human rights. Similarly, the fertility decrease largely depends on the changing economic value of children and shiftment of productive system from agriculture to industrialization and modernization. This interpretation has been challenged by those who claim that the flow of wealth in preindustrial societies is always from parent to child rather than from child to parent. That's; why, in preindustrial society where the children usually work for subsistence of family and higher the children higher will be the subsistence and population for subsistence, while in case of industrial society, higher the children higher will be sharing, divide property and lesser will be the saving and economic value of the population is for generating economic subsistence by working overtime.

The economic models of fertility decline is largely determined by demand for children or the demand of ideal family size and supply of children which is able to control the fertility. In the course of development of society, mostly agrarian or subsistence agricultural modes of production shifted towards the industrial or commercial modes of production. At the moment use of technology is very high and it replaces the huge labor forces ultimately creates the pressure on fertility decline. While in the course of social change, transition from agriculture to industrial modes of production ultimately demands the situation from "quantity" to "quality", also helps to decline fertility. In other hand, in industrial or commercial or in capitalistic society, the cost of single child is very heavy as compared to the child grown up in agricultural society, that's why it is pressure to decline fertility and people follow with references of ideal family. Second theory is fertility decrease or increase is directly proportionate with their reproductive success, and infant and child mortality. Fertility decrease when the rate of infant and child survival will be high and fertility increase when survival rates are low. Fertility decreases if the norms, values, perceptions or say knowledge about ideal family size and birth control practices spread more quickly in culturally homogeneous populations. There was popular Nepalese proverb, "two children are the blessing of God". This theory proposes the reorientation of our old value system and attitudes. We should remodel the thinking pattern about fertility decline in a way as; why fertility declines? quite better than the question; how do people adjust to declining mortality?

Fertility decrease is largely determined by infant mortality and female empowerment. However, role of economic value of children's labor plays an important role in fertility decisions. Fertility decrease or increase has reciprocity with empowerment of women and if women gain more autonomy and control over their own lives they reduce their fertility levels because, among other possibilities, higher levels of fertility present them with serious burdens. 
Sociobiology provides the understanding of human behavior and this world through the new dimensional perspective of extraordinarily complex blend of genetic and environmental factors to understand the human behavior. It focuses the role or the importance of cultural variability, or the increasing role of technology in widening the limits of our biological constraints (Dahal, 2020b).

\subsection{Theories about Son Preferences}

In many societies, son preference is so common and sex-selective practices during pre-birth gets high value and that only sons carry out certain functions like continue lineage system, maintaining the patriarchy and also performs the some religious and cultural traditions, such as death rituals for parents. "Society as living organism" and its parts can be examined with respect to how they operate (or function) to maintain the viability of the body social as it grows and develops, therefore, examine the social significance of phenomena, that is, the purpose they serve a particular society in maintaining the whole (Craib, 1997). Spencer's theory is filled with analogies between organisms and society as well as between ecological processes (variation, competition, and selection) and societal evolution (which he saw as driven by war). Durkheim argued that sociological explanations "must seek separately the efficient cause of a phenomenon and the function it fulfills" (Craib, 1997), but, in contrast to Spencer, he posited only one functional requisite: the need for social integration. In Durkheim's sociological analysis the assessment of the causes of phenomena and their consequences or functions for meeting the needs of social structures for integration should be involved. Malinowski visualizes the individual's function so as to satisfy their own need in "the theory of need" have suggested that individuals have physiological needs and to satisfy that individuals' need social institutions play key roles to satisfy theses needs, but unlike Malinowski's emphasis on individuals, Radcliffe-Brown considered individuals irrelevant in comparison to institution as a society is a system of relationships maintaining it through institutions that are orderly sets of relationships whose function is to maintain the society as a system. (Craib, 1997). Social justice and social morality are the fundamental theme and has been concerned of Sociology since the period of Marx, but, abuse of concepts of biology especially evolutionary biology or biosociology in the context of explaining cultural, racial and gender based similarities and differences.

\section{2.1 Social Darwinian Perspective on Son Preferences}

Herbert Spencer propounded the theory of Social Darwinism on the basis of Darwin's concepts of Natural Selection through the survival of the fittest. Social Darwinism was used to justify differences in terms of cultural behaviors among them the role of such cultural factors like technology, inventions, cultures, society, traits, norms, values, attitudes are important to influence the biological factors like; gene, race, gender, geography, climate etc in reference to their adaptations.

The genes are unit of heredity through which the characters, features and behavior of parents are transferred from a parent to offspring and is culturally practiced through the lineage system inherited by son i.e. gene determines the features and characteristics of organism. Human behavior can be subjected to game theory for their gene selection through their successiveness and adaptation in environment (Daly \& Wilson, 1988). In this sense, human society is either biosociological or sociobiological interaction of human species; intra- and inter- genetic species competitions for their selections and fitness to adopt in their environment. The former considers geographical and later historical factors, in contrast, includes the level of the individual organism and a society of species.

\subsubsection{Sociobiological Perspective}

The son preference practices are more common even in those countries that are well practicing gender harmony and gender solidarity either for dowries, bride price, gifts or to discriminatory inheritance laws help to drive such practices such as female infanticide. Son preference is a symptom of pervasive social, cultural, political and economic injustices against daughter or against the whole women, and a manifest violation of women's human rights. Son preference refers to the differential ability of individuals with different phenotypes to compete successfully for mates by producing traits that are attractive to prospective mates and sexual selection increases the chances of an individual's reproductive success. In case of human, mate selection especially son preference is generally guided by fitted genes in terms of physically, mentally, socio-culturally advances and smarts for individual's reproductive success.

That's why; Sociobiology studies a human behavior and cultural traits that son gets preference in Hindu society in a comparative perspective, and provides a general explanation about the evolution of such behavior and culture like in many other species or in some respects in uniquely human ways in which, the role of cultural variability, or the increasing role of technology in widening the limits of our biological constraints.

\subsubsection{Ecological Perspective}

Ecological perspective on son preference is also another alternative perspective to analyze the human behavior and cultural traits in a wider sense. Ecology acts as a major component of human behavioral and cultural variations; either 
genetic variation through geographical isolation or by adaptation or cultural variations. The interplay between nature and nurture i.e. biology vs sociology are usually studied in terms of human behavior and cultural traits. Here, nature vs. nurture debate has had significant social implications, particularly concerning on to determine people's ability to learn. Due to ecological constraints the discriminatory behavior on own bundles of gene affect parental behavior and the differential treatment of sons and daughters. Female infants and fetuses are at risk only under certain particular and predictable cultural-ecological conditions such as plow agriculture, herding, patrilineal inheritance, dowry, and low resource contribution by women ( Bugos \& McCarthy, 1984).

Sociobiology rejects a dualistic view of heredity versus environment, nature versus nurture, and substitutes an integrated view of human behavior as the complex product of the interaction, but it also assumes human language and culture as extremely important as outcome of a process of biological evolution and evolution of culture, but continues to interact reciprocally with both our genotype and our physical and biotic environment (Van Den Berghe, 1978).

\subsubsection{Economic and Demographic Perspective}

Economy and demography are both important factors in society and culture and the family plays a fundamental role in reproducing the division, discrimination and hierarchy, among and between caste, class, genders etc. According to Malthusian principle, resources have reciprocal relation with population and an economic value child is important in industrial society and family also plays its part in "regulating" the labor market. The theory of sexual economics assume that economic marketplaces; usually the law of supply and demand becomes unrest, when demand is high there is pressure on supply side and prices became high, and if when supply exceeds demand, the price will be low, favoring buyers (men). The economic theory emphasized on the differentiation on sex role in economy (Baumeister \& Vohs, 2004). The focus of sexual economics theory is that women are the sellers and men are the buyers. Economic capital signifies money, property, or other financial assets that indicate one's class and status.

\subsubsection{Gender Perspective}

The gender theory emphasized on the role of socio-structural and cultural-psychological factors for the discriminating gender status and role in family, society and culture. Lynn Bennett juxtaposed the Mary Douglas's notion "power and dangers credited to social structure are reproduced in small in the human body" in studying the Hindu society to control the fertility, sexuality of women through the cultural traits and practices in the name of pollution and danger (Bennett, 1983). Likewise, as parallel with Sandy's theory of "female power and male dominance", Bennett interestingly established the role of socio-cultural factors such as; myths, ethos, religions weenies, etc. to control over the female fertility, sexuality and mobility as dangerous forces in the name of cultural, religious, social and psychological in Hindu society.

Bennett established the issue of control on women's mobility, sexuality and fertility is not only because of the patriarchy and male domination. It is also because of the female too and she explored the interrelationship especially the tension between mother-in-laws and daughter-in-laws. After two or more than two children especially sons, her status has increased, considerably, and she may feel that, the authority of her mother-in-laws no longer has to be accepted without question. The conflicting relationship between affinal women, one is a mother -in law and other is daughter in -laws, because both want to enjoy power, authority and opportunity within family guided by patriarchy and male. This type gender socialization is institutionalized in family and kinship of Hindu and usually, parents are the first and most crucial agents of gender socialization that helps to socialize the women's social roles in Hindu kinship and family structure are related to their symbolic roles in cultural, economic and social sphere of life in Hindu society (Bennett,1983).

It is concluded that there are inter play between gene, ecology, socialization, evolutionary history, economy, demography, culture, etc and other human associated components, in which one inter play with one another reciprocally.

\section{Methods and Methodology Employed}

This research work was conducted in Kathmandu valley. By nature, this research is qualitative but to justify the some issues quantitative data were used to identify the facts about research topic and sub topics. During the course of research study qualitative research design with data collection methods like semi-structured interviews, observations were carried out among 100 married and educated middle-class mothers in Kathmandu are selected as respondent by using pseudonyms. I have changed the details of respondents, identity and their other information such as field of work and studies to preserve their anonymity. Interviews were conducted in Nepali language with respondents of educated middle-class married women with newly married and planning to conceive baby very soon.

The sample respondents are from the orthodox Hindu Society where son gets high value and daughter will not. Such discriminative socio-cultural patterns are the fundamental criteria and they have access to and knowledge of ultrasound and sex-selective abortions, which means that various social factors including, marital status, size of family, composition of family sex, their numbers and sex ratio (Saggurti et al., 2011). The Kathmandu valley was chosen as a study area that represents the other areas in urban Nepal where the respondents of the research topic could be found easily and fertility 
decrease, son preference could be found in working couple very easily. Here, I selected 9 case-study on Hindu households that represented middle class families which is rigid in single child especially son. I interviewed the married women in whom my research topic is concentrated using a semi-structured, open- ended format for an average of five times during my research. In rarely found the joint-family household, the case studies was first focus with both the mother-in law and the daughter-in-law. These mothers-in-law, together with women in nuclear family households who were of an age at which they were socially recognized as no longer reproducing (that is, they had at least one grandchild), make up the group I refer to as "mothers-in-law." Daughters-in-law and the women of socially recognized reproductive age in the nuclear family households make up the category I refer to as "young mothers."

\section{Findings and Presentation}

\subsection{Reciprocity between Family Size and Fertility and Single Child}

Kathmandu valley is practicing nuclear family system without separation. Mostly, family members are belongs to the joint family system with nuclear setting and residence, i.e. overall members and property are commonly or jointly owned and share but they live separate for their own purpose for performing business, job and for education etc. that's why Nepalese families are commonly said "emotionally joint but practicing nuclear". It is found from this study that the households in Kathmandu valley are set up, the size of family and the socio-economic status of family are determined by the attitudes on conceiving child mostly son.

Another common reason for family fragmentation situations that found study area also verified through the documentations, films and television shows related with family quarrel and family fragmentation along with their property share that the relationship between the mother-in- law and her daughter-in-law and migration stands as another reasons revealed by respondents for forming a nuclear household to find work, education, opportunities, family fragmentation due to family quarrel and elopement to form a love marriage. But now a day due to modernization and due to the freedom inside family, people want nuclear family rather than joint and people want mostly few child(mostly single) rather than more. With various reasons, transformation of production system from agro-based to non agro-based economic and production system, lacks of family members to care child, because of low income and opportunities about birth control services, and due to the rise of education etc. promote the decline of fertility and give birth few child. Fertility is decreasing not only because of demographic reason but also because of economic, socio-cultural, ecological, religious, emigration, occupations, individualism, etc. and fertility behavior is also transmitted from one generation to the next mostly related to genes.

In addition, the debate on nature vs nurture is also the important which shows the impacts of natural factor with socialization play important role in fertility behavior. It is found from the field studied in Kathmandu that, the great desire for sons ultimately creates the imbalance of sex ratio through which various socio-cultural behavior of people will be changed and decrease in fertility without changes in attitudes regarding son preference could be at the cost of increased use of sex-selective abortions or female infanticide (Leone et al., 2003).

\subsection{Socialization about Fertility and Son Preference}

Socialization play important role in the fertility patterns and selection of number and gender of child. The attitudes and perception of individual is highly influenced by his own genetic behavior and his/ her family and the society where he or she socializes. So, the socialization process based on social learning and social influence through family, society, culture and peers is also a major mechanism explaining family size correlation (Bernardi 2016).

Family is the first and primary school of an individual and family size preferences seem to be exerted through social pressure and subjective obligation (Bernardi 2003), which are shaped during childhood. By a mimetic effect or through moral obligations, growing up within a large or small family may thus increase preferences for the same type of family size through a desire to perpetuate the family image instilled during childhood (Lois \& Arránz Becker 2013). The socialization process and its outcomes vary within the family composition, economic status, social structure and cultural and religious composition of the family and society. The transformation of family based modes of production in to industry based production helps to promote migration and family form and similarly, religious dimension of the society and the attitudes developed by it in society and individual also impacts on the increase or decrease of fertility levels and ideals. It is found that, the large changes in the structure of society over the century (in terms of social classes and religion) were certainly crucial in explaining the change in the intergenerational family size correlation. In France, the social groups that shrunk over the century more often had very small families (e.g., employers, including shopkeepers) or very large families (e.g., farmers or manual workers).

We thus expect the drop in the share of families with a small or large-family culture to reduce fertility transmission, particularly the transmission of extreme family sizes. In addition, opportunities for social mobility (Glass et al. 1986), mass education (Breen 2010), and the decline in religious adherence within families (Lehrer \& Chiswick 1993) may have 
weakened the link between parents' and their children's family sizes.

Among study samples, it is found the same impacts which were observed and studied by many scholars in many empirical reviews that in the course of social development, family size is decreasing with decreasing the fertility rate, because of migration, seeking opportunities etc. and many more.

\subsection{Economy, Fertility and Son Preference}

From the perspective of parental investment son preference has got priority and sex differences are usually shaped by the processes of mate selection, intra group heterosexual selection; inter group sexual selection and their competition. The general principle of the sex selection for parental investment is usually males make a smaller parental investment than females and females tend to be more discriminating in mate choice because of their greater costs of reproduction, because of males benefit more so from numerous mating opportunities than females, they were selected to invest more effort in mating than females, while females allocate proportionally more effort to improve the quality of their offspring.

Kathmandu is the urban city where the domination of working class people found. Economy determines the all sphere of human's social life and social strata are mainly determined through the economic condition, property, income and occupations. The occupational structure is often construed to represent the pattern of socioeconomic opportunity in modern societies especially in industrial and urban (Rose, et. al., 2009). In another way, through the occupational structure the level of socio-cultural disparities are also identified and the level of discrimination and segregation of various social groups (by gender and race) since occupational attainment is rarely determined solely by an individual's choice alone (Gill, 1989).

Majority of the respondents prefer son as her child In middle class families in Kathmandu, people want mostly single child and from the economic point of views, male has unlimited capacity to produce, reproduce and the wages for male sex is higher than female. The data found from the field work that, occupation is another component on determining the sex of child which they want to born. Usually, the reply of the questions about their opinion on gender selection and preborn child, they replied that they wanted a son that's why they are now in the process of getting him very soon. Similarly, in response to why you want to get a son rather than daughter, most of the respondent replied that, " son is a son who will handle all works very comfortable, successfully, because they are brave and they can handle everything very easily now and they will take care of all in old age while we will not able to do any task and care ourselves". Likewise, their voice was found "Son is essentially significant in our culture, they can continue our lineage, take care our parental properties, and status of parents what they earned during their life. Son only can worship and remember our soul after death".

It is found from the study of samples that the economy is the main decisive factor for the determination of family size, fertility rate. It is also found that not only income, parental property, occupations, economic value of children, mode of productions etc are key factors that determine the fertility rate and family size including gender of the children especially son performance. Usually in case of Kathmandu, due to the occupation, working culture husband and wife, difficult to share parental property single child is mostly liked and that child must be male i.e. son.

\subsection{Religions and Son Preference}

There is a close relationship between religious identity, beliefs and practices with the selection of sex of their child. In demographic studies, there is a cultural explanation for the son preference in the influence of religion on fertility (Goldscheider \& Uhlenberg, 1969), who indicated that there may be multiple sources for fertility differences between different religious groups. There is a culture of son preferences that found in most of the religious and cultural group flourish their own religious perception, values, attitudes, norms and traits. It was found that, middle class family of Hindu religious background in Kathmandu mostly follow the Hindu values and norms in which son is the means to go the path towards heaven is easy and sure.

It is found from the literature review that, most of the regions have their own perspective in case of gender discriminations and son preferences in which the son gets high value and daughter gets low. Male stands for ruling class and female for ruled class.

\subsection{Single Child and Eagerness of Son}

It was found from the study that the sampled women of Kathmandu valley openly expressed their opinion in the conceiving the single child and desire of son in their household during the fieldwork. If they do not able to produce son there will be the situation of co wives in their households to produce sons although they are educated and they know the rules about and against it. In patriarchal society like in Nepal, son preference is institutionally through culture and religion by developing the patriarchal ideology which favors sons over daughters. Sex-detection of a fetus is mainly conducted for an abortion if the fetus is found to be female, it resulted the imbalance of sex ration in long run (Unnithan-Kumar, 2005). 


\section{Discussion and Analysis}

There are various factors that are influencing the fertility decrease and son preferences. Among them, ecological factor is the one that influence the differential treatment of sons of daughters and extreme forms of gender discrimination leading to male-biased sex ratios. Male- biased sex ratios could contribute to a culture that valorizes masculine and feminine beliefs. Fraternal polyandry may be another option (Goldstein, 1971, Goldstein, 1976). In case of mate selection, men have to be successful and competitive in order to find a mate, while, the socioeconomic mobility of women seems to have a paradoxical effect on the treatment of daughters in new socio-natural environment. Since others in educated middle-class of Kathmandu are under tremendous pressure to ensure the financial and academic success of their sons, highly educated women in male-biased sex ratio in educated middle-class of Kathmandu tend to invest more in their sons than in their daughters. It seems that a combination of economic success and internalization of idealized notions of masculinity may improve the reproductive success of men among educated middle-class of Kathmandu. However, such idealized notions of masculinity could also be a source of stress affecting the psychological well being of men ((Das Gupta \& Visaria, 1996, Mahalingam, 2007).

Fertility in Nepal is determined by migration which is the one of the key factor and migration determines whether fertility increase or decrease. Children get high value because they help in household task and very simple tasks that are in farm also frees to mother and other family members form their overloaded works in household or in farm. Although fertility has been decreasing in Nepal since 1981, it is still high compared to many other developing countries because Nepal still follows the at least two children in a family while in some other countries single child is mandatory. Generally, increasing migration trends must decrease the use of contraceptives but in case of Nepal both are increasing now a day. From the study it is concluded that, in a modern, heterogeneous, complex, advance society and culture that are practiced in traditional patterns of thinking are still prevalent and continue to define gender roles and practices especially among the middle-classes that found in Kathmandu.

Similarly, it is found that women and patriarchy are playing key role to establish the son performance in educated middle-class of Kathmandu. Institutions of society, such as family and marriage perpetuate the norms of gender inequality and reproduce them in daily interactions between men and women. The absence of a son leads family members and social networks to put pressure on women to have a son, affecting their reproductive choices. It also mentioned that during the field work respondent considered socially constructed gender inequality as normal and natural and legitimized it through their son preference practice. Even respondents did not challenge their subordination and dependence upon men and instead considered them socially and biologically weaker and inferior to men.

Likewise, economic factors; access on parental property, occupations, wages, etc play a vital role in the determination of sex and fertility associated with son preference. Except these demographic factors like migration, mortality rate and population compositions etc are also important factors for the sex selections and fertility decrease. The economic value of male, cultural attitudes, perception towards male not the matter of demographic composition to maintain the equilibrium in sex ration, but it is a matter of security for female in groom's home after give birth the son directly impacts on the fertility decrease.

Social structure of the society itself is a causal factor for the fertility decrease and son preferences. Development of education, modern nuclear family structure, newly amendment social rules and regulation, new dimension on social behaviors etc are also helps to promote decrease fertility and son preference in Kathmandu valley. Patriarchy and patriarchal social system always play key role in fertility decrease and son preferences. Social discrimination on mobility of son and daughter shows the role of social factors in the discriminations between son and daughter. That's why people always want son rather than daughter.

Cultural values and norms are also factors for the determination of fertility rate and son preferences in Kathmandu. Kinship system, lineage system, marriage systems, types of marriage, fear about polygyny, religious values, etc are more common factors that always insist the decrease or increase of fertility proportionally with son preferences.

Political factors are also other important factors for the determination of fertility rate. Population policies of the country, property rights, economic policies, etc are also directly or indirectly influencing the fertility decrease.

\section{Conclusion}

Fertility is not only determined by the demographic factors rather than it is highly determined by many other factors like economic, ecological, social, political, cultural religious and psychological etc. Ecological factors like climate, topography, availability of natural resources, technology adopted, or say socio-natural system are the main determining factor for it. So, it is a complex one which should be studied by using multidisciplinary approach. Similarly, economic factors; access on parental property, occupations, wages, etc play a vital role in the determination of sex and fertility associated with son preference. In this study, fertility was also determined by ecological factor rather than contraceptive 
use. Fertility is directly related with migration. Despite all factors like increasing age at a marriage, increasing knowledge about contraceptives uses, increasing socio-economic level of people, increasing access towards contraceptives etc., and migration is the one of the main factors to determine the fertility in Nepal. Except these, cultural factors are also playing determining role on what should be the population dynamics especially fertility.

Cultural values and norms are also factors for the determination of fertility rate and son preferences in Kathmandu. Kinship system, lineage system, marriage systems, types of marriage, fear about polygyny, religious values, etc are more common factors that always insist the decrease or increase of fertility proportionally with son preferences. Social structure of the society itself is a causal factor for the fertility decrease and son preferences. Development of education, modern nuclear family structure, newly amendment social rules and regulation, new dimension on social behaviors etc are also helps to promote decrease fertility and son preference in Kathmandu valley. Likewise, political factors are also other important factors for the determination of fertility rate. Population policies of the country, property rights, economic policies, etc are also directly or indirectly influencing the fertility decrease.

Therefore, son preference, for the middle-class women in Kathmandu should not be understood superficially, it is a complex whole and it should be studied comprehensively and critically through the integrated approaches.

\section{References}

Agnihotri, S. B. (1995). Missing females: a disaggregated analysis. Economic and Political Weekly, 30(33), $2074-2084$.

Arnold, F., Kishor, S., \& Roy, T. K. (2002). Sex-selective abortions in India. Population and Development Review, 28(4), 759-785. https://doi.org/10.1111/j.1728-4457.2002.00759.x

Banaji, M., \& Greenwald, A. (2013). Blind spot: Hidden Biases of Good People. New York: Delacorte Press.

Barot, S. A. (2012). Problem-and-solution mismatch: son preference and sex-selective abortion bans, Guttmacher Policy Review, 15(2), 18-22.

Baumeister, R. F., \& Vohs, K. D. (2004). Sexual economics: Sex as female resource for social exchange in heterosexual interactions. Personality and Social Psychology Review, 8, 339-363. https://doi.org/10.1207/s15327957pspr0804_2

Bennett, L. (1983). Dangerous Wives and Sacred Sisters: social and symbolic roles of High Caste women in Nepa. New York, Columbia University press.

Bernardi, L. (2003). Channels of social influence on reproduction. Population Research and Policy Review, 22, $527-555$. https://doi.org/10.1023/B:POPU.0000020892.15221.44

Bernardi, L. (2016). The intergenerational transmission of fertility. In M. C. Buchmann (Ed.), Emerging trends in the social and behavioral sciences, Wiley Online Library. https://doi.org/10.1002/9781118900772.etrds0413

Blau, P., Duscan, M., \& Dudley, O. (1967). The American occupational structure. New York: John Wiley \& Sons.

Breen, R. (2010). Educational expansion and social mobility in the 20th century. Social Forces, 89, $365-388$. https://doi.org/10.1353/sof.2010.0076

Bugos P. E., \& McCarthy, L. M. (1984). Ayoreo infanticide: A case study, In: Hausfater G, Hrdy SB (Ed.). Infanticide: Comparative and evolutionary perspectives, New York: Aldine, 503-520.

CBS. (2011). Preliminary Results of Nepal population Census 2011. Kathmandu, Nepal

Clark, S. (2000). Son preference and sex composition of children: evidence from India. Demography, 37(1), 95-108. https://doi.org/10.2307/2648099

Craib, I. (1997). Classical Social Theory, London; Oxford University Press.

CREHPA/UNFPA (2007a). A Rapid Assessment on Sex Ratio at Birth in Nepal with Social Reference to Sex Selective Abortion and Infanticides, UNFPA, Kathmandu

Dahal, B. P. (2020 b). Society and Sex Selection; Son Preference among the Educated Middle-Class in Kathmandu. Advances in Anthropology, 10, 147-168. https://doi.org/10.4236/aa.2020.102009

Dalla Z. G., \& Leone, T. (2001). A gender preference measure: the sex ratio at last birth. Genus, LVII(1), 33-57.

Daly, M., \& Wilson, M. (1988). Evolutionary social psychology and family homicide, Science, 242(4878), 519-524. https://doi.org/10.1126/science.3175672

Darwin, C. (1871). The descent of man and selection in relation to sex, London: John Murray. https://doi.org/10.5962/bhl.title.24784

Das Gupta, M. (1987). Selective discrimination against female children in rural Punjab, India. Population and Development Review, 13(1), 77-100. https://doi.org/10.2307/1972121 
Das Gupta, M., \& Visaria, L. (1996). Son preference and excess female mortality in India's demographic transition. In: Sex preferences for children and gender discrimination in Asia. Seoul, Korea: Korea Institute for Health and Social Affairs, UNFPA, 6-102.

DHS. (2011). Nepal Demographic and Health Survey 2011, Kathmandu, Nepal: MOHP/Nepal, New ERA/Nepal, and ICF International.

George, S. (1997). Female infanticide in Tamil Nadu, India: From recognition back to denial? Reproductive Health Matters, 5(10), 124-132. https://doi.org/10.1016/S0968-8080(97)90093-8

Gill, A. M. (1989). The role of discrimination in determining occupational structure. Industrial and Labor Relations Review, 42(4), 610-623. https://doi.org/10.1177/001979398904200410

Glass, J., Bengtson, V. L., \& Dunham, C. C. (1986). Attitude similarity in three-generation families: Socialization, status inheritance, or reciprocal influence? American Sociological Review, 51, 685-698. https://doi.org/10.2307/2095493

Goldscheider, C., \& Uhlenberg, P. R. (1969). Minority Group Status and Fertility. American Journal of Sociology, 74(4), 361-372. https://doi.org/10.1086/224662

Goldstein, M. C. (1971). Stratification, polyandry, and family structure in central Tibet. Southwestern Journal of Anthropology, 27(1), 64-74. https://doi.org/10.1086/soutjanth.27.1.3629185

Goldstein, M. C. (1976). Fraternal polyandry and fertility. Human Ecology, 4(3), $223-233$. https://doi.org/10.1007/BF01534287

Gupta, M. D., Jiang, Z., Li, B., Xie, Z., Woojin, C., \& Bae, H. O. (2003). Why is son preference so persistent in East and South Asia? A cross-country study of China, India and the Republic of Korea. Journal of Development Studies, 40(2), 153-187. https://doi.org/10.1080/00220380412331293807

Gursky, D., Hauser, B., \& Robert M. (1984). Comparative social mobility revisited: models of convergence and divergence in 16 countries. American Sociological Review, 49(1), 19-38. https://doi.org/10.2307/2095555

Karki, Y. B. (1992). Sex ratio in Nepal. Economic Journal of Nepal, 15(1), 30-37. https://doi.org/10.3126/jcmsn.v15i1.20753

Lehrer, E. L., \& Chiswick, C. U. (1993). Religion as a determinant of marital instability. Demography, 30, $385-404$. https://doi.org/10.2307/2061647

Leone T., Matthews Z., \& Zuanna G. D. (2003). Impact and determinants of sex preference in Nepal. International Family Planning Perspectives, 29(2), 69-75. https://doi.org/10.2307/3181060

Lois, D., \& Arránz Becker, O. (2013). Is fertility contagious? Using panel data to disentangle mechanisms of social network influences on fertility decisions. Advances in Life Course Research, 21, $123-134$. https://doi.org/10.1016/j.alcr.2013.10.001

Mahalingam, R. (2007). Beliefs about chastity, machismo and caste identity: A cultural psychology perspective. Sex Role, 56(3-4), 239-249. https://doi.org/10.1007/s11199-006-9168-y

Miller, B. (1997). The Endangered Sex: Neglect of Female Children in Rural North India, Delhi. Oxford University Press.

Ministry of Health (Nepal). New Era and ORC Macro (2006), Nepal Demographic and Health Survey, Family Health Division, Ministry of Health, New Era and ORC Macro, Calverton, Maryland US.

Puri, M., Ingham, R., \& Matthews, Z. (2007). Factors affecting abortion decisions among young couples in Nepal. Journal of Adolescent Health, 40(6), 535-542. https://doi.org/10.1016/j.jadohealth.2007.01.010

Rose, D., \& Harrison, E. (Ed.). (2009). Social class in Europe: an introduction to the European socio-economic classification, London: Routledge.

Saggurti, N., Mahapatra, B., Swain, S. N., \& Jain, A. K. (2011). Male migration and risky sexual behavior in rural India: is the place of origin critical for HIV prevention programs?. BMC Public Health, 11(6), 1-13. https://doi.org/10.1186/1471-2458-11-S6-S6

Symons, D. (1979). The evolution of human sexuality. Oxford University Press, New York.

Robert, T. (1972). Parental investment and sexual selection. Sexual Selection \& the Descent of Man, Aldine de Gruyter, New York, 136-179.

UNFPA (2007). Gender equality and empowerment of women, UNFPA, Kathmandu, Nepal 
Unnithan-Kumar, M. (2010). Female selective abortion-beyond 'culture': family making and gender inequality in a globalising India. Culture, health \& sexuality, 12(2), 153-166. https://doi.org/10.1080/13691050902825290

Unnithan-Kumar, M. (2005). Introduction', in M Unnithan-Kumar (ed.). Reproductive Agency, Medicine and the State, 1-24, New York, Oxford: Berghahn Books.

Van Den Berghe, P. L. (1978). Sociobiology: A New Paradigm for the Behavioral Sciences?. Social Science Quarterly, 59(2), 326-332.

Williams, G. (1979). The changing US labor force and occupational differentiation by sex. Demography, 16(1), 73-87. https://doi.org/10.2307/2061080

Witherspoon, D. J., Wooding, S., Rogers, A. R., Marchani, E. E., Watkins, W. S., Batzer, M. A., \& Jorde, L. B. (2007). Genetic similarities within and between human populations. Genetics, 176(1), 351-359. https://doi.org/10.1534/genetics.106.067355

\section{Copyrights}

Copyright for this article is retained by the author(s), with first publication rights granted to the journal.

This is an open-access article distributed under the terms and conditions of the Creative Commons Attribution license (http://creativecommons.org/licenses/by/4.0/). 